\author{
REVIEW OF EUROPEAN AND COMPARATIVE LAW \\ VOLUME XXXII \\ YEAR 2018
}

\title{
HUNTING RIGHTS IN POLAND
}

\author{
Witold Danitowicz*
}

ABSTRACT

Although hunting rights constitute the key element of Polish hunting law, so far they have not been subject to detailed analysis in legal writings devoted to the subject. This is most likely due to the fact, that the term itself is not used in the hunting legislation. The article fills this gap. It analyzes the legal nature of hunting rights under Polish law as well as examines legal issues most closely related to this legal institution, namely hunting preserve and hunting lease. Also analyzed is the ownership of game at large, game carcass, hunting trophies and shed antlers.

Key words: Hunting law, hunting rights, real rights, hunting lease, hunting preserve, game, game ownership

\section{EXISTENCE AND CONTENT OF HUNTING RIGHTS}

The term "hunting rights" in the most general sense refers to the exclusive right to hunt game in a given territory ${ }^{1}$. Since the imposition of the socialist system in 1944 this term has not been used in Polish hunting legislation in

* Dr Witold Daniłowicz, J.D., LL.M., is a member of the bar of legal advisors in Warsaw, Poland, and Of Counsel with the law firm of Noerr Biedecki sp.k., witold.danilowicz@gmail.com.

1 "Hunting rights" is an English language term which corresponds to prawo polowania in Polish, Jagdrecht im subjektiven Sinn in German and droit de chasse (in a narrow sense) in French. 
the post-war period. This should be attributed to both the nationalization of hunting rights in 1952 by the Decree on Hunting Law (the "1952 Decree") as well as the legislature's reluctance to use terminology that was reminiscent of the old regime. It appears, however, that while the legislature intended to draft new hunting laws without the use of this term, it never intended to eliminate hunting rights as a legal institution from Polish law.

It is the thesis of the present study that even though not named, hunting rights, as a legal institution, have survived in Polish law and are present in the Hunting Law of $1995^{3}$ (the "Hunting Law") currently in force. The existence of hunting rights in the Hunting Law is evidenced by the structure of this legislation. Certain of its other institutions, in particular hunting preserve (obwód towiecki $i^{4}$ ) and hunting lease (dzierżawa towiecka), rely upon this concept and cannot be properly understood without it. A hunting preserve is an area where the state may exercise its hunting rights. A hunting lease is a mental shortcut for a lease of hunting rights 5 .

The existence of hunting rights as a legal institution in the Hunting Law was confirmed by the Polish Constitutional Tribunal in $2014^{6}$ (the "2014 Judgment"). The Tribunal concluded that hunting rights belong to the state: "The analysis of the [Hunting Law] leads to the conclusion that hunting rights belong to the state, which regulates the exercise of such rights, granting the right to exercise them only to persons who meet certain criteria".

As the legislation is silent on the subject, the conclusion that hunting rights belong to the state (more precisely, to the State Treasury ${ }^{7}$ ) has to be arrived at by way of interpretation. The main argument in support of this

${ }^{2}$ Decree of 29.10.1995 on Hunting Law (Dekret z 29.10.1952 r. o prawie łowieckim, Dz.U. poz. 300 ze zm.).

${ }^{3}$ Law of 13.10.1995 - Hunting Law (Ustawa z 13.10.1995 r. - Prawo łowieckie, Dz.U. z 2017 r. poz. 1295 ze zm.).

${ }^{4}$ In cases where the English translation of a Polish language term might not be entirely clear, the relevant Polish term is provided in brackets.

${ }^{5}$ See the detailed discussion in parts 3 and 4 .

${ }^{6}$ Judgment of the Constitutional Tribunal of 10 July 2014, P/19/13, OTK-A 2014/7, poz. 71 .

${ }^{7}$ Under Polish law, the State Treasury is the embodiment of the state in private relations. 
conclusion can be drawn from Art. 29, sec. 1 of the Hunting Law, which determines who leases out hunting preserves.

Under Polish law, a right may be leased out only by a person to whom such right belongs. Article 29, sec. 1 of the Hunting Law provides that hunting preserves consisting mostly of woods are leased out by regional directors of the State Forests (Lasy Państwowe). Hunting preserves consisting mostly of agricultural land are leased out by heads of district administration starostowie) $^{8}$. As there is no reason to assume that the State Treasury has ceded hunting rights to such entities, it should be assumed that they lease them out in the name of the State Treasury. Consequently, it follows that hunting rights belong to the State Treasury.

An additional argument in support of this conclusion can be found in Art. 31, sec. 2 of the Hunting Law, which determines who is entitled to rent from the lease of a hunting preserve. As a general principle, rent from a lease belongs to the lessor, in whom the leased right is vested. The lessor may, however, assign such rent to another person. This is the case with rent from hunting leases. Under the cited provision of the Hunting Law, the holder of hunting rights and at the same time the lessor, i.e., the State Treasury, assigns rent proceeds to appropriate units of the State Forests (nadleśnictwa) and communes (gminy) where hunting preserves are located.

Traditionally, hunting rights comprise the exclusive right to raise, hunt and appropriate game. All these rights are also included in the content of hunting rights as they are structured by the Hunting Law. However, the lack of uniform and coherent terminology, as well as the imprecise formulation and organization of the relevant provisions of the Law, makes it difficult to precisely outline their content.

In addition to granting rights, the Hunting Law also imposes certain obligations on persons entitled to exercise hunting rights. Thus, lessees of hunting preserves ${ }^{9}$ are required to carry out hunting husbandry (gospodar-

${ }^{8}$ It should be noted in this context that in Poland, except at the ministerial level, there are no state organs in charge of hunting matters. Responsibility for managing hunting has been transferred by the state partially to the Polish Hunting Association and partially to the State Forests.

9 The terms „lessee of hunting rights" and "lessee of a hunting preserve" as used in this study refer to both a lessee of hunting rights in a hunting preserve and to a person charged 
ka towiecka) ${ }^{10}$, in accordance with principles set forth in the Hunting Law, based on annual and long-term plans. Under the Hunting Law, lessees of hunting rights are also obligated to protect game. While not stated directly, such obligation can nevertheless be found by way of interpretation of the definition of "hunting" as well as in the objectives of hunting stipulated in the Hunting Law. Lessees of hunting rights are further obliged to combat poaching.

One of the key obligations of lessees of hunting preserves is an obligation to compensate landowners for damage caused in tillage and agricultural produce by certain species of game - wild boar, moose, red deer, fallow deer and roe deer. The State Treasury is responsible for damages caused by game species which are subject to a year-round hunting moratorium on hunting as well as damages in areas not included in hunting preserves.

\section{LEGAL NATURE OF HUNTING RIGHTS}

The legal nature of hunting rights has never been analyzed in Polish legal writings. This can probably be explained by the fact that the term "hunting rights" is not used in the Hunting Law. Thus, it is likely that not all legal writers are aware of the existence of this legal institution.

Prior to their nationalization in 1952, hunting rights were clearly private rights. They were absolute, subjective rights of patrimonial character, which belonged to the landowner. Following nationalization, hunting legislation has been based on the principle that hunting rights belong to the state (State Treasury). Therefore, analysis of the legal nature of hunting rights, as they are structured in the Hunting Law, should commence with the question whether such rights have maintained their private nature following takeover by the state.

with managing hunting preserves excluded from leasing for the purpose of establishing a game management area pursuant to Art. 28, Sec. 2 of the Hunting Law.

10 "Hunting husbandry" (gospodarka towiecka), as such term is used in the Hunting Law, includes activity in the field of game care as well as raising and obtaining (hunting) it (Art. 3 Sec. 1). 
In a sense, hunting rights constitute a public law charge on real property. Their basis lies in statutory law as well as in the resolutions of local legislatures (sejmiki wojewódzkie) creating hunting preserves. Thus, the public law element is quite significant. Despite that, it appears that hunting rights remain private, subjective rights of a patrimonial nature.

The State Treasury exercises such rights primarily by leasing them to hunting associations (kota towieckie) pursuant to lease agreements ${ }^{11}$. Such agreements are civil law contracts. Entering into such contracts is an act of private, not public, law ${ }^{12}$. Consequently, hunting rights, as they are structured under the Hunting Law, constitute subjective private rights belonging to the State Treasury. Therefore, it is important to further examine their legal character as private rights.

The present analysis tests the premise that hunting rights are real rights (iura in rem). All real rights are related to a thing (res) and cannot exist without it. Thus, the question of which thing hunting rights are related to should be resolved at the outset. It should be noted in this context that the Polish Civil Code has adopted a narrow concept of a thing (res) and limited it to material objects only (Art. 45). Thus, in order for hunting rights to qualify as real rights, a connection has to be established between them and a thing with the meaning of Art. 45.

One of the first authors to analyze this issue in Poland was F. Zoll who analyzed it under the pre-war legislation. He concluded that the object of hunting rights is game. This determination led the author to the conclusion that because game at large is not considered a thing under Polish civil law (as it is not subject to human power), hunting rights cannot be considered real rights. This in turn resulted in F. Zoll including hunting rights in the group of rights which he called "rights similar to real rights" 13 .

${ }^{11}$ A hunting preserve may be excluded from leasing to a hunting association in order to establish a game management area (ośrodek hodowli zwierzyny) pursuant to Art. 28, Sec. 2 of the Hunting Law.

${ }^{12}$ Certain authors take the view that a hunting lease is an administrative contract and a state organ entering into such contract performs an administrative act. See the discussion below in part 4 .

${ }^{13}$ Other rights in this group included inter alia fishing rights, mining rights and rights to inventions (F. Zoll, Prawo cywilne w zarysie, vol. II, Prawo rzeczowe, Kraków, 1947, 22 et seq). 
The present analysis proposes instead that land (real property) should be considered an object of hunting rights. Such rights cannot exist without the physical space (ground) within which they are exercised. As pointed out by R. Longchamps de Bérier, the exercise of hunting rights essentially involves "taking possession of game on a given ground" 14 . This connection to ground, a material object and a thing within the meaning of the Civil Code would make it possible to include hunting rights among real rights. However, the existence of a connection with a thing is necessary, but not sufficient, for treating hunting rights as real rights. Therefore further analysis of the relationship between hunting rights and real rights is required.

There is no generally accepted definition of the term "real rights" in Polish law. Most authors agree that such rights, in addition to being connected with a thing, are both patrimonial and absolute. That hunting rights are patrimonial is rather obvious and requires no proof. They are also absolute as they are effective against third parties (erga omnes). This means that everybody is obliged to respect the exercise of such rights by the State Treasury and the lessees of such rights.

An infringement on a real right entitles the holder to defend it by means of a real action (actio in rem). Arguably, such action could also be used to defend against the infringement of hunting rights in a claim of a lessee of hunting rights against a landowner for allowing hunting on property located within a hunting preserve or for ceasing interference with the use of such property for hunting purposes.

The presented analysis leads to the conclusion that hunting rights have all the characteristics of real rights. They are created by statute, are connected with a thing (ground), have patrimonial character and are absolute. They can also be enforced by way of a real action.

The last obstacle that prevents qualifying hunting rights as real rights under Polish law is the principle of numerus clausus of such rights adopted by the Polish Civil Code. Only those rights named in the Code as real

${ }^{14}$ R. Longchamps de Bérier, Wstęp do nauki prawa cywilnego ze szczególnem uwzględnieniem kodeksów obowiązujących w b. Królestwie Kongresowym, w Małopolsce i W. Ks. Poznańskim, Lublin, 1922, 73. 
rights qualify as such ${ }^{15}$. The Code establishes three categories of real rights - ownership, permanent usufruct and limited real rights. Hunting rights do not fall into any of the three categories. Consequently, they do not qualify as real rights within the meaning of the Civil Code.

As hunting rights have the characteristics of real rights, but cannot be treated as such for the formal reason indicated above, it is proposed that they be considered quasi real rights ${ }^{16}$. Such qualification would allow for the application, at least by analogy, of the rules governing real rights to the exercise and protection of hunting rights.

At the moment, hunting rights are treated as special rights regulated by the Hunting Law. Their legal nature is not entirely clear and, as a consequence, it is not clear which rules govern their exercise and protection. Treating hunting rights as quasi real rights would allow for the application of the Civil Code rules to the civil law relations resulting from the exercise of hunting rights. Most importantly, such rules would govern, inter alia, relations between the lessees of such rights on the one hand and the landowners on the other.

\section{HUNTING PRESERVE}

Hunting rights can be exercised principally in hunting preserves. The Polish system of hunting preserves is based on the concept of large preserves (minimum size of 3,000 hectares) leased to hunting associations. The key feature of this model is the lack of a connection between hunting rights and ownership of the land on which preserves are created.

Hunting preserves are created on all land suitable for hunting, regardless of whether it is privately or state owned. However, unlike in other

${ }^{15}$ It has been suggested by some Polish authors that it might be advisable to expand the notion of real rights to include certain rights other than the rights identified in the Civil Code as real rights. See e.g. P. Machnikowski, "Ogólne wiadomości o prawie rzeczowym”, [in:] System prawa prywatnego, vol. 3, Prawo rzeczowe, (ed.) E. Gniewek, Warszawa, 2013, 708 .

${ }^{16}$ Under German law some authors also consider hunting rights to be real rights. See D. Meyer-Ravenstein, Die Jagdberechtigungen, Bückeburg, 1986, 32-33. See also H.P. Westermann, BGB - Sachenrecht, Heidelberg 2012, 9, Side No. 21. 
countries which adopted similar model ${ }^{17}$, in Poland private landowners whose land is included in a hunting preserve and who are obliged to tolerate hunting on their property by third parties receive no compensation for it. Nor can they hunt themselves on their property ${ }^{18}$. Owners of large tracts of land, regardless of their size, may not establish private preserves.

A hunting preserve is defined by the Hunting Law as a "contiguous ground area, covered by its borders, no smaller than three thousand hectares, suitable for hunting activities" (Art. 23, sec. 1). In addition to land which is not suitable for hunting activities, certain other areas listed in the Hunting Law are excluded from hunting preserves, namely, national parks, land within municipal borders and other built-up areas (Art. 26).

The Hunting Law describes a hunting preserve as a certain area, i.e., ground (real property). It would appear that this is simply a mental shortcut. Its use can be explained by the fact that the legislation does not employ the term "hunting rights." In fact, a hunting preserve is a hunting law institution which refers to a given area suitable for hunting, within which the State Treasury may exercise its hunting rights by way of leasing them to hunting associations.

As a result of leasing hunting rights in a hunting preserve the lessee acquires the exclusive right to exercise all the rights included in the content of the hunting rights, within the bounds of the preserve. Such understanding of a hunting preserve appears to better reflect its legal nature and makes it easier to understand the legal nature of a hunting lease.

\section{HUNTING LEASE}

The State Treasury exercises hunting rights primarily by way of leasing them to hunting associations. What constitutes the object of a hunting

${ }^{17}$ Primarily Germany, Austria and Luxemburg.

${ }^{18}$ Assuming he meets certain statutory criteria, a landowner may apply for a membership in a hunting association leasing a hunting preserve created on his land, but the association is not obligated to accept him as a member. A landowner residing within the hunting preserve has the priority in admission to the hunting association leasing such preserve. 
lease and its legal nature is matter of a debate in both the jurisprudence and legal literature. While some courts and authors treat hunting lease as a lease of real property ${ }^{19}$, others treat it as a lease of rights ${ }^{20}$. Within the latter group, various views are expressed with regard to the question of what rights are being leased.

The Hunting Law refers to a hunting lease as a "lease of a hunting preserve." This again is a mental shortcut employed for the sole reason that the law does not employ the term "hunting rights." As a result, the Hunting Law describes an object of a hunting lease in a simplified way, suggesting that it is a lease of certain land. In fact, a hunting lease is a lease of rights, namely, hunting rights, in a particular hunting preserve.

The legal nature of a hunting lease has also been subject to debate in both the jurisprudence and legal literature ${ }^{21}$. In this debate, two opposing views have emerged. According to the first view, a hunting lease is an administrative contract, which is one of the means in which the public administration fulfills its tasks ${ }^{22}$. The second view considers a hunting lease as a civil contract for the lease of rights within the meaning of Art. 709 of the Civil Code ${ }^{23}$.

The latter approach is supported by the case law of the Supreme Court. In a leading opinion on the subject, that court confirmed the civil law nature of a hunting lease although it stressed its uniqueness. One

${ }^{19}$ W. Radecki, Prawo łowieckie. Komentarz, Warszawa, 2014, 168; R. Stec, Uprawianie łowiectwa i prowadzenie gospodarki łowieckiej. Uwarunkowania administracyjnoprawne, cywilnoprawne i organizacyjne, Warszawa 2012, 69; L. Jastrzębski, "Uwagi uzupełniające glosę do wyroku SN z dnia 9 marca 1973 r., I CR 58/73", Nowe Prawo 6(1975): 912.

${ }^{20}$ J. Szachułowicz, "Problematyka prawna dzierżawy obwodów łowieckich”, Przegląd Sądowy 4(2002): 50; A. Lichorowicz, "Dzierżawa”, In: System prawa prywatnego. Prawo zobowiązań - część szczegółowa, vol. 8, Z. ed. Radwański, Warszawa, 2011, 193; M. Pryciak, "Własność w łowiectwie", Wrocławskie Studia Erazmiańskie 3(2009): 326.

${ }^{21}$ This debate dates back to the $19^{\text {th }}$ century - see, e.g., T. Bresiewicz, Ustawodawstwo łowieckie w Europie, Lwów, 1898, 33-35.

22 See W. Lipko, "Komentarz do art. 14”, In: L. Jastrzębski., W. Lipko, Prawo łowieckie. Komentarz, Warszawa, 1978, 24-25. See also R. Stec, Uprawianie, 70.

${ }^{23}$ See J. Szachułowicz, Problematyka, 50. See also W. Radecki., Prawo, 168; A. Pązik, "Obwody łowieckie", in: A. Pązik, M. Słomski, Prawo łowieckie. Komentarz, Warszawa 2015, 95; T. Müller, Z. Zwolak, Prawo łowieckie z komentarzem oraz przepisami wykonawczymi i związkowymi, Warszawa, 1998, 95. 
of the particularities identified by the Supreme Court was the manner in which such contracts are concluded and, in particular, the absence of negotiations ${ }^{24}$. Administrative courts have expressed the same attitude towards hunting leases, uniformly holding that they have no jurisdiction over disputes concerning hunting leases, thus pointing to their civil law character ${ }^{25}$.

Notably, a different view on this subject was taken by the Constitutional Tribunal. In the 2014 Judgment, the Tribunal took the position that by entering into hunting leases the regional administration carries out its public tasks. It follows, therefore, according to the Tribunal, that a hunting lease is an administrative or public contract.

It appears that treating hunting leases as a civil law contract for the lease of hunting rights best reflects their legal nature. Nevertheless, it is clear that hunting leases exhibit several special features differentiating them from typical lease agreements. The mandatory presence of certain provisions and their content are key examples of the difference. The mandatory provisions concern the term of the lease (no less than 10 years) as well as the amount of rent. The maximum amount of rent is set by the Hunting Law ${ }^{26}$. These special features result from the fact that one of the parties to the contract is the State Treasury, which performs its public function.

\section{FRUITS OF LEASE OF HUNTING RIGHTS}

\section{A. OWNERSHIP OF GAME}

In ancient Rome game was considered res nullius ${ }^{27}$. The same approach continues today in most European countries, including France, Germany

${ }^{24}$ Judgment of the Supreme Court of 19 December 2002, II CKN 978/00.

${ }^{25}$ See, e.g., Order of the Supreme Administrative Court of 22 August 2000, IV CKN $1150 / 00$.

${ }^{26}$ Rent paid by hunting associations is not related to and does not reflect the market value of the leased hunting rights. It is usually significantly lower than the market value.

${ }^{27}$ Justinian's Institutes, Book 2, Section 2.1, Birks P., McLeod G. (trans.), Ithaca, 1987. 
and Austria ${ }^{28}$. In some countries legislation provides that game is owned by the state. This group includes Russia, Lithuania and Poland ${ }^{29}$.

The Hunting Law provides that "wild game at large, as a national good (dobro ogólnonarodowe), constitutes the property of the State Treasury" (Art. 2). Various opinions have been expressed to explain the meaning of this provision. Its interpretation was further complicated by the adoption in 1997 of the Law on the Protection of Animals ${ }^{30}$. According to this legislation, animals "are not things" (Art. 1, sec. 1). Nevertheless, in the next section the law provides that the legal rules applicable to things do apply to animals (sec. 2).

Commenting on the legal status of game in light of these two legislative acts, certain authors reached the conclusion that Art. 2 of the Hunting Law, when read in conjunction with Art. 1 of the Law on the Protection of Animals, creates a civil right of ownership of game vested in the State Treasury. They admit, however, that such right exhibits significant public law elements ${ }^{31}$.

${ }^{28}$ Although in both France and Austria there are no legal provisions specifically regulating this issue, game is considered res nullius by both doctrine and jurisprudence. (See e.g. P. Lecourtier, Le droit de la chasse, Paris 1935, 12; B. Méraud, Le droit de la chasse. Manuel juridique, Nantes 2015, 445-446; A. Charlez, Le droit de la chasse, Paris 2014, 122 (regarding France), and G. Anderluh, Ch. Havranek, Kärntner Jagdrecht, Klagenfurt 2002, 22, Side No. 6 (regarding Austrian land Carynthia (there is no federal hunting law in Austria)). In Germany, the relevant rule is contained in $\$ 960$ Para 1, first sentence, of the BGB. (See also F. Baur, J. Baur, R. Stürner, Sachenrecht, München, 2009, 365, Side No. 68).

${ }^{29}$ In Russia the matter is regulated in Sec. 2 of the Rules on Hunting and Hunting Husbandry of the RSFRR (Положение об охоте и охотничьем хозяйстве РСФСР, Утверждено Постановлением Совета Министров РСФСР от 10 октября 1960 г., N 1548, http:/pravo.gov.ru/proxy/ips/?docbody=\&nd=102080528\&rdk=\&backlink=1, [date of Access: 11.02.2018]). (See also N.W. Krajew, W.N. Krajewa, ”O juridiczeskom statusie dikich żywotnych, obitajuszczich w sostojanii jestiestwiennoj swobody, sodierżaszczichsia i razwodimych w niewole i połuwolnych usłowijach", Adwokat 10.10 2016: 26. For Lithuania see Art. 3 Sec. 1 of the Lithuanian Hunting Law (Medžioklès įstatymas 2002 m. birželio 20 d. Nr. IX-966, „Žinios” 2002, Nr 65-2634; 2002, Nr 112-0, i. k. 1021010ISTA00IX-966).

${ }^{30}$ Law of 21.081997 on the Protection of Animals (Ustawa z 21.08.1997 r. o ochronie zwierząt, Dz.U. z 2017 r. poz. 1840 ze zm.).

${ }^{31}$ W. Radecki, Prawo, 6. A similar view was expressed by W.J. Katner (W.J. Katner, "Przedmioty stosunku cywilnoprawnego", in: System prawa prywatnego, vol. 3, Prawo cywilne - część ogólna vol. 1, ed. M. Safjan, Warszawa, 2012, 104). 
Other authors have suggested that Art. 2 of the Hunting Law creates a right which is not an ownership right within the meaning of the Civil Code, but instead is a subjective right "similar (analogous) to ownership" ${ }^{2}$. This view was shared by the Supreme Administrative Court, which in an obiter dictum expressed the view that following the entry into force of the Law on the Protection of Animals, the ownership of game has to be understood as an ownership right which is not ownership within the meaning of the Code. This is due to the fact that the object of such right is not a thing under the Code ${ }^{33}$.

A similar position was taken by yet another group of authors who see the "ownership of game" as falling outside the concept of ownership within the meaning of the Civil Code. Nevertheless, they are of the opinion that all the rules of the Code concerning real relationships and dealing in things also apply to game $\mathrm{e}^{34}$. The authors advancing this view do not explain, however, how to properly understand the term "ownership" used in Art. 2 of the Hunting Law.

All the authors participating in the debate described above assume that by introducing Art. 2 into the Hunting Law, the legislature intended to regulate the legal status of game in the context of real rights. It seems likely, however, that the introduction of Art. 2 served a different purpose. It appears that this provision of the Hunting Law was intended to serve as a legal basis (justification) for the granting of hunting rights to the State Treasury.

Before hunting rights were taken over by the state in 1952 they were connected with landownership. When that link was broken and hunting

${ }^{32}$ M. Goettel, Sytuacja zwierzęcia w prawie cywilnym, Warszawa, 2013, 61-62. See also K. Piernik-Wierzbowska, "Systematyka i zagadnienie własności zwierząt oraz ich statusu prawnego w kontekście problematyki odpowiedzialności za szkody przez nie wyrządzane", Studia Iuridica Toruniensia 16(2015): 230, and sources cited therein.

${ }^{33}$ Judgment of the Supreme Administrative Tribunal of 3 November 2011, II OSK/2011. The case involved animals other than game.

${ }^{34}$ E. Gniewek, "Komentarz do art. 45 kc", in: Kodeks cywilny. Komentarz, (eds.) E. Gniewek, P. Machnikowski, Warszawa, 2016, Side No. 4; E. Gniewek, Prawo rzeczowe, Warszawa, 2014, Side No. 122. See also; E. Skowrońska-Bocian, "Komentarz do art. 45 KC", In: Kodeks cywilny, vol. I. Komentarz do art. 1-449 11 , (ed.) K. Pietrzykowski, Warszawa, 2008, Side No. 5. 
rights were appropriated by the state, the legislature was in need of a legal basis for this new model of hunting regulation. This was most likely the reasoning behind the introduction of state ownership of game. It seemed to justify the argument that hunting rights belong to the state as the state owns all game.

An attempt to justify state appropriation of hunting rights by the state ownership of game does not appear very persuasive. This is because the state does not own game in the civil law sense of the word. As explained above, game is not a thing within the meaning of Art. 45 of the Civil Code and, as such, is not capable of being an object of ownership. As long as it remains at large, game is a material object not subject to any subjective right (res nullius).

This reasoning leads to the conclusion that Art. 2 does not regulate the legal status of game from the standpoint of real rights. Nor does it provide a legal basis for the hunting rights belonging to the State Treasury. At most, this particular provision of the Hunting Law could therefore be viewed as a foundation for an argument that the state has the right to regulate hunting.

\section{B. GAME CARCASS AS THE FRUIT OF A LEASE OF HUNTING RIGHTS}

In ancient Rome, game was treated as res nullius and therefore when obtained during a hunt it became the property of the hunter by way of occupation (occupatio). This principle was reflected in the Justinian's Institutes: "Wild animals [...] become the property of the taker as soon as they are caught" ${ }^{35}$. The same principle operates today in most European countries ${ }^{36}$.

${ }^{35}$ Justinian's Institutes, Book 2, Section 2.1.

${ }^{36}$ With respect to French law see F. Colas-Belcour, "V V Chasse, Fasc. 10: Chasse. Définition. Sources. Organisation", Juris Classeur Rural 12.07.2014 (updated 18.04.2016), DOI: www.lexis360.fr (31.05.2016 r.), thesis 58. The author points out that under French law even a poacher acquires ownership of caught game (F. Chabas, "Biens: droit de propriété et ses démembrements" in: H. Mazeaud, L. Mazeaud, J. Mazeaud, F. Chabas, Leçons de droit civil, vol. II, Paris, 2014, 290, thesis 1581). With respect to German law see $\$$ 958 of the BGB. See also E. Metzger, "Jagdrecht", in: A. Lorz, E. Metzger, H. Stöckel, 
The Hunting Law provides that game killed during a lawful hunt belongs to the lessee of hunting rights (Art. 15, sec. 1). It does not, however, identify the manner in which this ownership right is acquired. Some authors take the view that since game is owned by the State Treasury it is not res nullius and therefore cannot be subject to occupation ${ }^{37}$. Others argue that even though game is owned by the State Treasury, ownership of killed game is nevertheless acquired by way of occupation ${ }^{38}$. It has also been suggested that when game is killed "there takes place a sui generis renouncement of the right of "ownership" by the State Treasury and simultaneous acquisition of such right by the entitled person." ${ }^{39}$. Finally, some authors hold the traditional view that game at large is not a thing and therefore is not owned by anybody. It only becomes a thing upon its capture or killing and at such time it becomes property by way of occupation.

This last approach seems to best describe the manner in which the ownership of hunted game is acquired. Following this rule, however, title to game obtained during hunting would belong to the hunter who obtained it. Article 15, sec. 1 of the Hunting Law modifies this result by providing that game killed during a lawful hunt belongs to the lessee of hunting rights. This regulation is by all means correct, as the game carcass is the fruit of a hunting lease and as such should belong to the lesse $e^{40}$. A hunter hunting legally in a game preserve does so with the permission of and, in a sense, in the name of the lessee.

Thus, in order to determine the manner in which the ownership of game carcasses legally hunted in a hunting preserve are acquired one

Jagdrecht, Fischereirecht. Bundesjagdgesetz mit Verordnungen und Hinweisen zum Länderrecht, Binnen- und Seefischereirecht. Wichtige Vorschriften des Grundgesetzes, Strafgesetzbuchs, Tierschutzgesetzes und Waffengesetzes. Kommentar, München, 2010, 21, Side No. 23. With respect to Austria (Carynthia) see G. Anderluh, Ch. Havranek, Kärntner..., 2, Side No. 6.

${ }^{37}$ A. Stelmachowski, "Nabycie i utrata własności", in: System prawa prywatnego, vol. 3, Prawo rzeczowe, (ed.) T. Dybowski, Warszawa, 2012, Side No. 203. See also M. Nazar, "Normatywna dereifikacja zwierząt" In: Prawna ochrona zwierząt, ed. M. Mozgawa, Lublin, 2002, 142.

${ }^{38}$ W.J. Katner, Przedmioty, Side No. 109.

${ }^{39}$ M. Goettel, Sytuacja, 110-111.

${ }^{40}$ Under German law game carcass is also considered natural fruit of the hunting rights (M. Wolff, L. Raiser, Sachenrecht. Ein Lehrbuch, Tübingen, 1957, 298, fn. 18). 
should examine two legal provisions - Art. 181 of the Civil Code and Art. 15, sec. 1 of the Hunting Law. The earlier determines that the ownership of game is acquired by occupation. The latter determines that the owner of the carcass is the lessee of hunting rights.

Similar reasoning could be used with respect to game hunted illegally (poached) in a hunting preserve. Based solely on Art. 181 of the Civil Code, a poacher would become the owner of the carcass. In order to avoid this result, Art. 15, sec. 2 of the Hunting Law modifies the general rule and provides that game acquired illegally in a hunting preserve belongs to the State Treasury. It is not clear why the law provides for a different result in this case when compared to the situation when the game is acquired during a lawful hunt. It appears that in both cases, i.e., game hunted legally and illegally, the carcass should be treated as the fruit of a hunting lease and should belong to the lessee of hunting rights. It should be noted that poaching results in a damage to the lessee of the hunting rights who raises game in a hunting preserve.

The legal status of a carcass of an animal which lost its life in any way other than as a result of a hunt (lawful or unlawful) is not regulated in the Hunting Law. This issue concerns game which died of natural causes, as a result of an accident or was killed by another animal. In Germany, the right to obtain such carcass constitutes a hunting right. In Poland it does not, as the lessee of hunting rights acquires title only to game "obtained in a hunting preserve in accordance with the law." In the cases described above, the game was not "obtained."

The traditional view on this subject in Polish legal writing has been that the legal status of a game carcass in such situation is governed by the rules applicable to lost things. It has been proposed that, unless special regulations grant ownership to the carcass to another person, it belongs to the State Treasury as the "owner" of game. Consequently, the person who finds such carcass should, in accordance with the rules on lost property, notify the appropriate state authority ${ }^{41}$. This proposition seems untenable. Game carcass constitutes the natural fruit of a hunting lease within the meaning of Article 54 of the Civil Code, regardless of the way in which the

${ }^{41}$ W. Lipko, Komentarz, 24-25; T. Müller, K. Zwolak, Prawo, 34-35; M. Pryciak, Własność, 325. 
animal lost its life. This approach provides a legal basis for the proposition that the ownership of a game carcass found in a hunting preserve should always belong to the lessee of hunting rights in such preserve.

The presence of game in a hunting preserve as well as its condition is, to a large extent, the result of the efforts of the lessee of hunting rights. In the event of an animal killed by a poacher or dying either from natural causes or as a results of an accident, it is the lessee who suffers a loss. It is therefore only sensible for the lessee to be accorded title to the carcass, particularly if it has monetary value.

\section{OWNERSHIP OF HUNTING TROPHIES AND SHED ANTLERS}

From the hunters' perspective, the ownership of hunting trophies is of crucial importance. Nevertheless, this matter is not regulated in the Hunting Law. Thus, the answer to this question has to be arrived at by way of interpretation.

When game is obtained by a hunter, it becomes a thing within the meaning of the Civil Code. At that moment, it becomes the property of the lessee of hunting rights in the preserve where the game was hunted. This rule refers clearly to the entire carcass, including those parts which constitute hunting trophies, as they are component things of a carcass within the meaning of Art. 47 of the Civil Code.

The lessee of hunting rights may either sell the carcass to a game dealer or to the hunter who obtained it. In the latter case, the lessee will customarily charge a price which is lower than the amount which the lessee would have obtained from a dealer. Regardless of how the lessee disposes of the rest of the carcass, the hunter who obtained the game is customarily allowed to keep hunting trophies. From a legal standpoint, the hunter obtains the trophies from the lessee by way of a donation.

Another issue requiring clarification is the legal status of shed antlers ${ }^{42}$. In some countries such as Germany, the right to collect such antlers is included in the content of hunting rights. In Poland, the Hunting Law

${ }^{42}$ Antlers are extensions of the skull grown by male members of the deer family. They are shed and regrow each year. 
does not address this issue. In the legal literature, shed antlers are viewed as autonomous things that cannot be owned until such time as they are found and taken into possession. Thus, their ownership is acquired by way of occupation by the person who found them.

It is difficult to agree with this approach. It should be pointed out that shed antlers are, at least partially, the result of husbandry efforts on the part of a lessee of a hunting preserve. Their quality is influenced by several factors, including the quality of the feed, often provided or at least supplemented by the lessee. Antlers have financial value and are traded in the market. For all these reasons, they should be considered the fruits of a hunting lease. As such, they are not res nullius and should belong to the lessee of the hunting rights. Such concept is reflected for example in German and Austrian hunting regulations, which specifically include the right to collect shed antlers within the scope of the hunting rights ${ }^{43}$.

\section{CONCLUSIONS}

Hunting rights as a legal institution of hunting law are present in Polish hunting legislation even though the term itself is not used by it. They are vested in the State Treasury. In principle, hunting rights have the characteristics of real rights (iura in rem). Nevertheless, they cannot be treated as such under Polish law because of the principle of numerous clausus of real rights followed by the Polish Civil Code. The present study proposes that they be considered quasi real rights. This would enable the application of the Civil Code rules pertaining to real rights by analogy to hunting rights.

A hunting preserve is an institution of hunting law which refers to a given area, suitable for hunting, within which the State Treasury may exercise its hunting rights by way of leasing them out to hunting associa-

${ }^{43}$ With respect to Germany see $\$ 5$ of the Federal Hunting Law (Bundesjagdgesetz vom 29. November 1952, BGBl. I S. 284), and with respect to Austria, where hunting is regulated at local level, see e.g. $\$ 1$ of the Carynthian Hunting Law (Kärntner Jagdgesetz, LGBl. Nr 21/2000 (WV)). 
tions. A hunting lease is a civil law contract for the lease of hunting rights, although it exhibits several special features differentiating it from typical lease agreements.

The rules governing ownership of a game carcass set forth in the Hunting Law should be modified. This issue should be regulated by a single rule, applicable regardless of the manner in which a given animal lost its life. In all cases, ownership of a carcass should accrue to the lessee of hunting rights as the natural fruit of a hunting lease. This rule should also be extended to cover shed antlers.

\section{REFERENCES}

Anderluh, Gerhard, Charlotte, Havranek. 2002. Kärntner Jagdrecht. Klagenfurt Bresiewicz, Tadeusz. 1898. Ustawodawstwo łowieckie w Europie. Lwów Jastrzębski, Ludwik. "Uwagi uzupełniające glosę do wyroku SN z dnia 9 marca 1973 r., I CR 58/73", Nowe Prawo 6:912-913

Baur, Fritz, Jürgen, Baur, Rolf, Stürner. 2009. Sachenrecht. München

Chabas, François., 2014. "Biens: droit de propriété et ses démembrements" In:

H. Mazeaud, L. Mazeaud, J. Mazeaud, F. Chabas, Leçons de droit civil, vol. II. Paris

Charlez, Annie. 2015. Le droit de la chasse. Paris

Colas-Belcour, François. 12.07.2014 (updated 18.04.2016). "V ${ }^{\circ}$ Chasse, Fasc. 10:

Chasse. Définition. Sources. Organisation". Juris Classeur Rural. DOI: www. lexis360.fr

Gniewek, Edward. 2016. "Komentarz do art. 45 kc". In: Kodeks cywilny. Komentarz, eds. E. Gniewek, P. Machnikowski. Warszawa

Gniewek, Edward. 2014, Prawo rzeczowe, Warszawa

Goettel, Mieczysław. 2013. Sytuacja zwierzęcia w prawie cywilnym, Warszawa Justinian's Institutes. 1987. trans. Peter Birks, Grant McLeod. Ithaca.

Katner, Wojciech, Jan. 2012. "Przedmioty stosunku cywilnoprawnego". In: System prawa prywatnego, vol. 3, Prawo cywilne - część ogólna vol. 1, ed. Marek Safjan. Warszawa

Lecourtier, Pierre. 1935 Le droit de la chasse. Paris

Lichorowicz, Aleksander. 2011. "Dzierżawa". In: System prawa prywatnego. Prawo zobowiązań - część szczegółowa, vol. 8, ed. Zbigniew Radwański, Warszawa 
Lipko,Wiktor. 1978. "Komentarz do art. 14”. In: Ludwik Jastrzębski., Wiktor Lipko. Prawo łowieckie. Komentarz, Warszawa

Longchamps de Bérier, Roman. Wstęp do nauki prawa cywilnego ze szczególnem uwzględnieniem kodeksów obowiązujących w b. Królestwie Kongresowym, w Małopolsce i W. Ks. Poznańskim, Lublin 1922

Machnikowski, Piotr. 2013. "Ogólne wiadomości o prawie rzeczowym". In: System prawa prywatnego, vol. 3, Prawo rzeczowe, ed. Edward Gniewek. Warszawa

Méraud, Bernard. 2015. Le droit de la chasse. Manuel juridique. Nantes

Metzger, Ernst. 2010. "Jagdrecht”. In: Albert Lorz, Ernst Metzger, Heinz Stöckel. Jagdrecht, Fischereirecht. Bundesjagdgesetz mit Verordnungen und Hinweisen zum Länderrecht, Binnen- und Seefischereirecht. Wichtige Vorschriften des Grundgesetzes, Strafgesetzbuchs, Tierschutzgesetzes und Waffengesetzes. Kommentar. München

Meyer-Ravenstein, Dietrich. 1986. Die Jagdberechtigungen, Bückeburg

Müller, Tadeusz, Zygmunt, Zwolak. 1998. Prawo łowieckie z komentarzem oraz przepisami wykonawczymi i związkowymi, Warszawa

Pązik, Adam. 2015. ”Obwody łowieckie” In: Adam Pązik, Marcin Słomski, Prawo łowieckie. Komentarz, Warszawa

Piernik-Wierzbowska, Kamila. 2015. ”Systematyka i zagadnienie własności zwierząt oraz ich statusu prawnego w kontekście problematyki odpowiedzialności za szkody przez nie wyrządzane”. Studia Iuridica Toruniensia 16:217 - 236

Pryciak, Marcin. 2009."Własność w łowiectwie”. Wrocławskie Studia Erazmiańskie 3:320-333

Radecki, Wojciech. 2014. Prawo łowieckie. Komentarz. Warszawa

Skowrońska-Bocian, Elżbieta. 2008. "Komentarz do art. 45 KC” In: Kodeks cywilny, t. I. Komentarz do art. 1-449 ${ }^{11}$, ed. K. Pietrzykowski. Warszawa

Stec, Roman. 2012. Uprawianie łowiectwa i prowadzenie gospodarki łowieckiej. Uwarunkowania administracyjnoprawne, cywilnoprawne i organizacyjne. Warszawa

Stelmachowski, Andrzej. 2012. "Nabycie i utrata własności" In: System prawa prywatnego, vol. 3, Prawo rzeczowe, ed. Tomasz Dybowski. Warszawa

Szachułowicz, Jan. 2002. "Problematyka prawna dzierżawy obwodów łowieckich”. Przegląd Sądowy 4:47-63

Westermann, Harm, Peter. 2012. BGB - Sachenrecht, Heidelberg

Wolff, Martin, Ludwig, Raiser. 1957. Sachenrecht. Ein Lehrbuch, Tübingen Zoll, Fryderyk. 1947. Prawo cywilne w zarysie, vol. II, Prawo rzeczowe. Kraków 
